Dept. of Zoonoses,

Faculty of Veterinary Medicine, Cairo University

\title{
CAPTIVE DOGS AS RESERVOIRS OF SOME ZOONOTIC PATHOGENS
}

(With 8 Tables)

\author{
By \\ MAHA A.S. and H.S. LOTFY* \\ * Animal Health Research Institute, Beni-Suef Branch \\ (Received at 20/11/2008) \\ الكلاب في الأسر كمخازن للأمراض المشتركة للمخالطين \\ مها أحمد صبري ، حسين سبي لطفي
}

لتقييم كفاءة عقار مضاد للايدان التي تصيب الكلاب تم اختيار كلاب ضالة مصابة طبيعيا

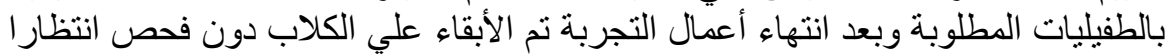

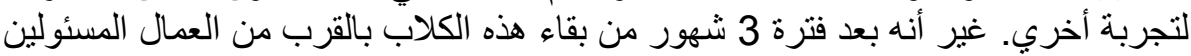

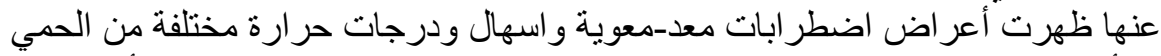

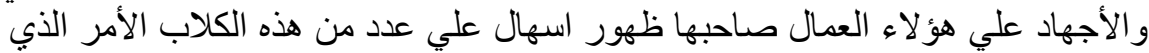

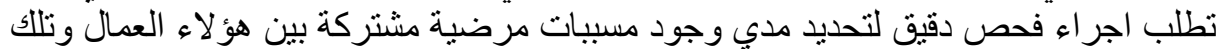

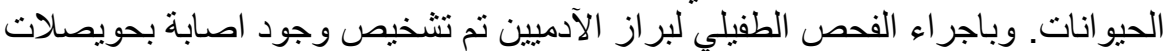

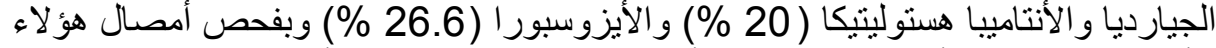

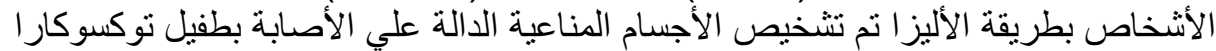

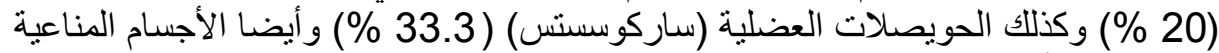

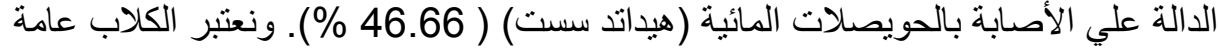

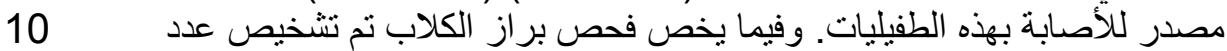

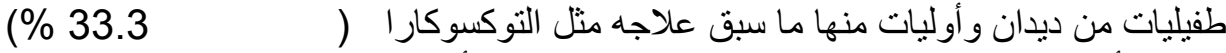

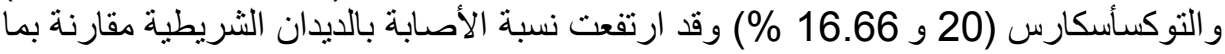

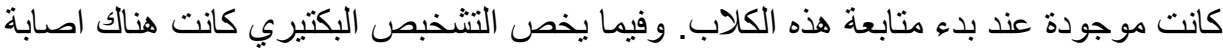

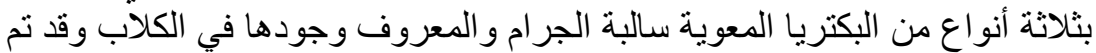

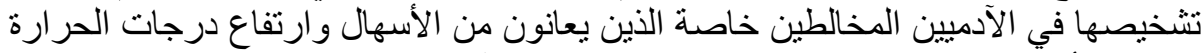

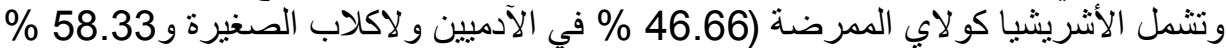

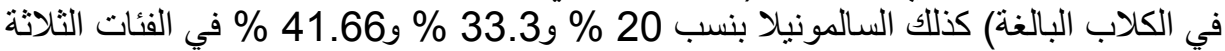

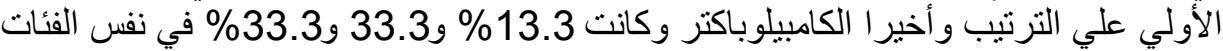

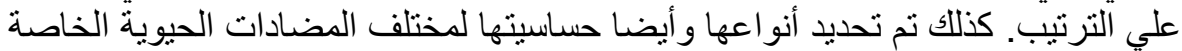

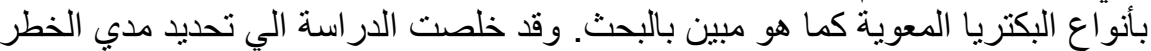

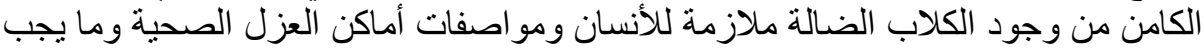

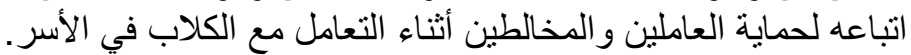


In the present study two groups of stray adults and puppies dogs were captive in small boxes for special drug trial. After 3 months the dog attendants complained with gastrointestinal disturbances, diarrhea, weakness, headache and fever. In the same time, some dogs are suffering from diarrhea also. Investigation of these cases revealed infection by several pathogens isolated from both attendants and dogs. Entamoeba histolytica, Giardia (trophozoites \& cysts) and Isospora species oocysts were diagnosed in feces of 20\%, 20\% and $26.6 \%$ respectively in attendants closely contact to dogs. Anti-Toxocara canis, anti-Sarcocystis and anti-hydatid cysts antibodies were diagnosed in 20\%, 33.3\% and $46.66 \%$ respectively in sera of attendants using EL1SA. Puppies and dogs were infected by Toxascaris leonina (20\% \& $16.66 \%$ ), Dipylidium caninum (53.33\% \& 66.66\%) and Taenia spp. eggs (26.6\% \& 50\%). Giardia (53.33\%), E. histotytica (13.33\%), Toxocara canis $(33.3 \%)$, Isospora (53.3\%) and Cryptosporidium oocysts (20\%) were diagnosed in puppies only. Two adult dogs $(16.66 \%)$ are shed Sarcocystis oocyst and Ancylostoma caninum eggs in their feces. Bacteriological examination of fecal swabs evidenced infection by 3 enteric bacteria in attendants, puppies and dogs. Salmonella (20\%, 33.3\% \& 41.66\%), Campylobacter $(13.3 \%, 33.3 \% \& 33.3 \%)$ and enterotoxigenic E.coli $(46.66 \%, 46.66 \% \& 58.33 \%)$. Serotyping of these bacteria revealed presence of $S$. typhimurium in dogs $(60 \%)$ and attendants $(66.6 \%)$, S.enteritidis in one of the worker as well as 8 untyped strains. Two serotypes of $C$. jejuni in 2 workers and 4 dogs, E. coli in 3 dogs, while 2 untyped isolates were recorded in dogs. Three serotypes of E. coli $(\mathrm{O} 26$, $\mathrm{O} 76, \mathrm{O} 55)$ and two untyped strains were isolated from workers and dogs. Moreover two isolates (O 5 \& O 111) were isolated from dogs only. The isolates showed high sensitivity for Gentamycin $(10 \mu \mathrm{g})$. The study recommended some precautions to minimize the role of captive dogs as a potential source of zoonotic pathogens.

Key words: Dogs, attendants, zoonotic, parasites, bacteria.

\section{INTRODUCTION}

Through out their long history of domestication, dogs have been source of zoonotic parasites and have served as a link for parasite exchange among livestock, wildlife and humans. Globally, dogs remain an important source of emerging diseases in humans (e.g eosinophilic enteritis by Ancylostoma caninum), a bridge for re-emerging infections (Echinococcus granulosus), and a source of parasites for 
immunocompromised persons (Egula-Aguilar et al., 2005). A number of potential enteropathogens have been isolated from dogs, most notably Salmonella sp. and Campylobacter species as well as enteroinvasive E. coli (EIEC). These pathogens represent an interesting combination of incidents, severity, stringency of industry standards and public awareness (Greene, 2006). Meanwhile, they have been clearly associated with acute and chronic disease, typically causing enterocolitis, but they can also be present in clinically healthy carriers which potentially present a risk to other animals and humans so that they represent a zoonotic risk. These pathogenic enteric bacteria are disseminated in feces from infected animals (Hall and Simpson, 2000).

Bacterial diarrheas are generally a nuisance for the adult animal but can be lethal to a small puppy, kitten, or even a human baby. Most of these problems stem from contaminated food or fecal contaminated environment. Raw food diets for pets dramatically increase the risk of human exposure (Brook, 2006).

The survival time of these bacteria varies significantly, as Campylobacter can survive for days in surface water and as long as 4 weeks in feces. In addition, the duration of excretion in infected dogs and cats can be as long as 4 months. Salmonellae can also survive for prolonged periods outside the host, especially in aquatic environments; shedding may continue for 3 to 6 weeks, and can be reactivated at a later date by any intercurrent stress (Hall, 2004).

On the other hand, dogs act as a source for a wide number of zoonotic parasitic infections that pose a significant threat to human health. This includes Dipylidium caninum, Toxocara canis, Ancylostoma caninum, Diphylobothrium latum, Giardia, Sarcocystis and Cryptosporidium (Habluetzel et al., 2003; Eguia-Aguiler et al., 2005, Pullola et al., 2006; Fontanarrosa et al., 2006; Martinez-Moreno et al., 2007).

During experimental trial on captive stray dogs, an infection problem was emerged in dog attendants after 12 weeks contact with these dogs. They were complained with digestive disturbances, diarrhea accompanied with different degrees of fever. These captive dogs are incriminated as the cause of this problem. The present study is a result of these attendants investigation as well as the contact captive stray dogs.

\section{MATERIALS and METHODS}




\section{Collected samples:}

Identified blood and fresh fecal samples were collected from:

\section{Human:}

Two groups of male animal workers were investigated. First group of five animal attendants who are responsible for feeding, cleaning and collecting samples from dogs captive in boxes, and the second group consists of 10 general animal workers and assistants in the same area of the study.

\section{Dogs:}

Stray dogs (12 adult females and 15 puppies of 3-5 months old) were kept for successive four months, captive in a concreted floor $1.5 \mathrm{~m}$ (length), 1.0 (width) and $2.0 \mathrm{~m}$ (height) pin with wire door at faculty of Veterinary Medicine Cairo University, Department of Surgery, Giza Egypt. The animals were allocated as 4 adults, or 5 puppies per each pin. Dogs were fed chicken bone and bread, while puppies were fed fresh bread, bread soaked in milk as well as chicken bone.

\section{Examination of samples:}

\section{1- Stool and fecal examination:}

\section{Parasitological examination:}

Each sample was examined macroscopically for detection of whole worms or part of worm. The suspected trophozoies, large size eggs and larvae were diagnosed using direct smear method (Solusby, 1986). Concentration flotation technique was adopted for diagnosis of different nematode eggs, cysts and oocysts according to Pullola et al., 2006), 5 gram of fecal sample were mixed with $70 \mathrm{ml}$ of concentrated $\mathrm{MgSO}_{4}$ and the mixture was sieved (mesh size $0.9 \mathrm{~mm}$ ) into $50 \mathrm{ml}$ flask. The flask was filled to the rim, cover slip was placed on the top, left for 30 min., then transferred carefully to examine under the microscope. Total number of different eggs, cysts and oocysts per gram of feces was calculated in each time using Mc-Master technique according to Soulsby (1986).

\section{Bacteriological examination:}

Swab from each fecal sample was immersed directly into nutrient broth, tetrathionate broth and then incubated for $18-24$ hours at $37^{\circ} \mathrm{C}$. Loopfuls from the broth were streaked onto blood agar, MacConky agar, Xylose-lysin desoxycholate agar (XLD), Eosine methylen blue (EMB) plates and Muller Hintoen agar in microaerophilic atmosphere (Abdel Aty and Rabie, 2003). The plates were Incubated at $37{ }^{\circ} \mathrm{C}$ for $24-48$ hours. The suspected colonies were picked up purified on trypticase soya agar and re-incubated at $37^{\circ} \mathrm{C}$ for another $24-48$ hours. 
Identification of the purified colonies were done concerning the differences in morphology, cultural and biochemical characters according to Koneman et al., (1992) and Quinn et al., (1994).

Serological Diagnosis:

1- Identification of Campylobacter:

Using ACCUPROBE ${ }^{\mathrm{R}}$ CAMPYLOBACTER CULTURE IDENTIFICATION TEST kit (GEN-PROBE INCORPORATE, Sandigo, CA 92121), the tested fecal samples were initially cultivated using Campy Thioglycollate medium for $16-24$ hours at $37^{\circ} \mathrm{C}$. Fifty $\mu 1$ from the turbid portion of the broth were added to the Prob Reagent tube and the test was run according to the kits manual for identification of 3 strains of Campylobacter (C. jejum, $C$. coli \& $C$. lari) using the control and reference samples associated with these kits.

\section{2- Identification of Salmonella and $\boldsymbol{E}$. coli:}

The isolated Salmonellae were serotyped according to Kauffmann-White Scheme (Kauffmann, 1972) using polyvalent and monovalent sera of Salmonella 0 and $\mathrm{H}$ sera (Wellcome Reagents Limited, England). The suspected E. coli colonies were biochemically identified using API 20 diagnostic strip (Bio Merieux, France) and the strains were identified serologically by commercial slide agglutination kit using polyvalent and monovalent somatic (0) and flagellar $(\mathrm{H})$ antigens (Difco Laboratories USA) according to Ewing (1986).

\section{Diagnosis of Giardia and Cryptosporidium infection:}

Two Copro-ELISA test RIDASCREEN ${ }^{\mathrm{R}}$ kits (R-Biopharm AG, Landwehrstr. 54, D-64293 Darmstadt, Germany) were used for diagnosis of infection in stool and fecal samples, one for Giardia (A C:1 101) and the other for Cryptosporidium (A C: 1201) via sandwich or antigen capture (sandwich) ELISA. The kits include ELISA plate ready coated with specific Monoclonal antibody. ready for binding with the parasite antigen in the suspected fecal suspension. Required diluents, washing solution, positive control samples, conjugate, substrate and stopping solution were supplied with the kits.

\section{Sere-diagnosis of some tissue parasites:}

ELISA test was adopted for determination the anti- parasite antibodies in human and dogs' sera. The required antigens and reference anti-sera were prepared as the following:

\section{Sarcocystis antigen:}


According to Gasbarre and Fayer (1984), bradyzoites of Sarcocystis were extracted from macroscopic cysts of naturally infected bovine esophagus (identified as Sarcocystis cruzi) by crushing in $0.01 \mathrm{M}$ phosphate buffered saline (PBS) $\mathrm{pH}$ 7.4. After washing by centrifugation, the bradyzoites were ruptured separately in few amount of PBS by repeated freezing thawing (3 times). The contents were sonicated using "Cole parmer ultrasonic Homogenizer" under 150 watt interrupted pulse output at $50 \%$ power cycle in ice bath. The suspension was centrifuged at $10000 \mathrm{rpm}$ at $4{ }^{\circ} \mathrm{C}$ for one hour. The supernatant was collected and dialyzed overnight in refrigerator against PBS, $\mathrm{pH} 7.2$ using a dialysis membrane (6000 to 8000 molecular weight cut off), its protein content was measured by the method of Lowry et al., (1951), allocated in $1 \mathrm{ml}$ vial and stored at $-70{ }^{\circ} \mathrm{C}$ until use.

\section{Toxocara canis and Dipylidium caninum crude antigen:}

According to Kagan et al., (1958), T.canis worms were collected from scarified naturally infected dogs. After several washing in PBS, their anterior part were cut out, washed repeatedly then homogenized using homogenizer (ULTRA- TURRAX Janke and Kunkel KG) with (0.01 M) PBS, pH 7.4 at 6000 r.p.m. for 20 minutes in ice bath. The supernatant was separated after centrifugation $(6000 \mathrm{rpm}$ for 20 minutes in ice bath). The protein content was measured, then stored as before. By the same way, crude antigens were prepared from scolex of Dipylidium caninum.

\section{Fertil Hydatid cysts fluid antigen (FHCFA):}

The antigens were prepared according to Ito et al., (1999) where the hydatid fluids were collected from fertile cysts of freshly slaughtered camel lungs (Cairo abattoir), and examined for their viability. The fluid of fertile cysts was clarified by centrifugation at $5000 \mathrm{rpm}$ for $15 \mathrm{~min}$ at $4{ }^{\circ} \mathrm{C}$, dialyzed against $5 \mathrm{mM}$ Tris-Hcl $\left(\mathrm{pH} \mathrm{7.4)}\right.$ ) for $48 \mathrm{hr}$ at $4{ }^{\circ} \mathrm{C}$. Their protein content was measured and stored as before.

\section{Rabbit hyper-immune sera (RHIS)}

RHIS were raised against the previous prepared antigens according to Langley and Hillyer (1989). Six 2-month-old white New Zealand rabbits were bled for negative control sera, and then injected with the previous antigens at a concentration of $1.2 \mathrm{mg}$ protein for each antigen, mixed in an equal volume of Freund's complete adjuvant, injected subcutaneously at different places in the back of rabbit. After 3 weeks, 3 consecutives injections of $0.4 \mathrm{mg}$ protein antigen in equal volume of Freund's incomplete adjuvant were given intramuscularly at biweekly intervals. Rabbits were bled from the ear vein for serum 
collection 10-14 days after the last injection. The collected sera were stored at $-20{ }^{\circ} \mathrm{C}$ until used.

N.B. The previous parasite antigens and RHIS are available from previous research works see Sabry (2007) and Sabry and Waheed (2008).

\section{Enzyme linked immunosorbent assay (ELISA):}

The test was done according to Voller et al., (1976). Optimization of antigen concentration, conjugate, positive and negative values were determined after checkerboard titration. The ELISA plate was coated with antigen (4 ug/ well), sera tested at 1:100 dilution. Horse- radish peroxidase (HRP) conjugated rabbit anti-dogs and antihuman IgG (H\&L), (P7414, Sigma), were used at 1: 2000 dilution. O.D values were measured using automatic plate reader (SLT Spectra, 812 SW 1) at $450 \mathrm{~nm}$. The positive ELISA value is that equal to double of the mean value of the negative control sample according to Zimmerman et al., (1985).

\section{Antimicrobial susceptibility testing:}

The disk diffusion method (Bauer et al., 1966) was used for susceptibility testing. Eight drugs were routinely used to test Gram negative enteric bacteria: Gentamycin (10 ug), Ampicillin (10 ug), Amoxicilin (20 ug), Nitrofurantoin (300 ug) Streptomycin (10 ug), Kanamycin (30 ug), Tetracyclin (30 ug) and cephalothin (30ug).

\section{RESULTS}

Table 1: Natural parasitic infection diagnosed in dog feces after collection from the field.

\begin{tabular}{|l|c|c|c|c|}
\hline \multirow{2}{*}{ Diagnosed parasites } & \multicolumn{2}{|c|}{$\begin{array}{c}\text { Infection in puppies } \\
(\mathrm{n}=15)\end{array}$} & \multicolumn{2}{c|}{$\begin{array}{c}\text { Infection in adult dogs } \\
(\mathrm{n}=12)\end{array}$} \\
\cline { 2 - 5 } & No. +ve & $\%$ & No. +ve & $\%$ \\
\hline T.canis & 10 & 66.67 & - & - \\
\hline A.caninum & - & - & 5 & 41.67 \\
\hline T. leonine & 3 & 20.0 & 6 & 50.0 \\
\hline D.caninum & 2 & 13.33 & 8 & 66.67 \\
\hline Taenia spp & 3 & 20.0 & 6 & 50.0 \\
\hline Isospora oocysts & 4 & 26.67 & - & - \\
\hline Giardia spp & 4 & 26.67 & - & - \\
\hline Cryptosporidium. & 5 & 33.3 & - & - \\
\hline Sarcocystis oocyst & - & - & 5 & 41.67 \\
\hline
\end{tabular}

Table 2: Parasites diagnosed in dogs after 3 months in captivity. 


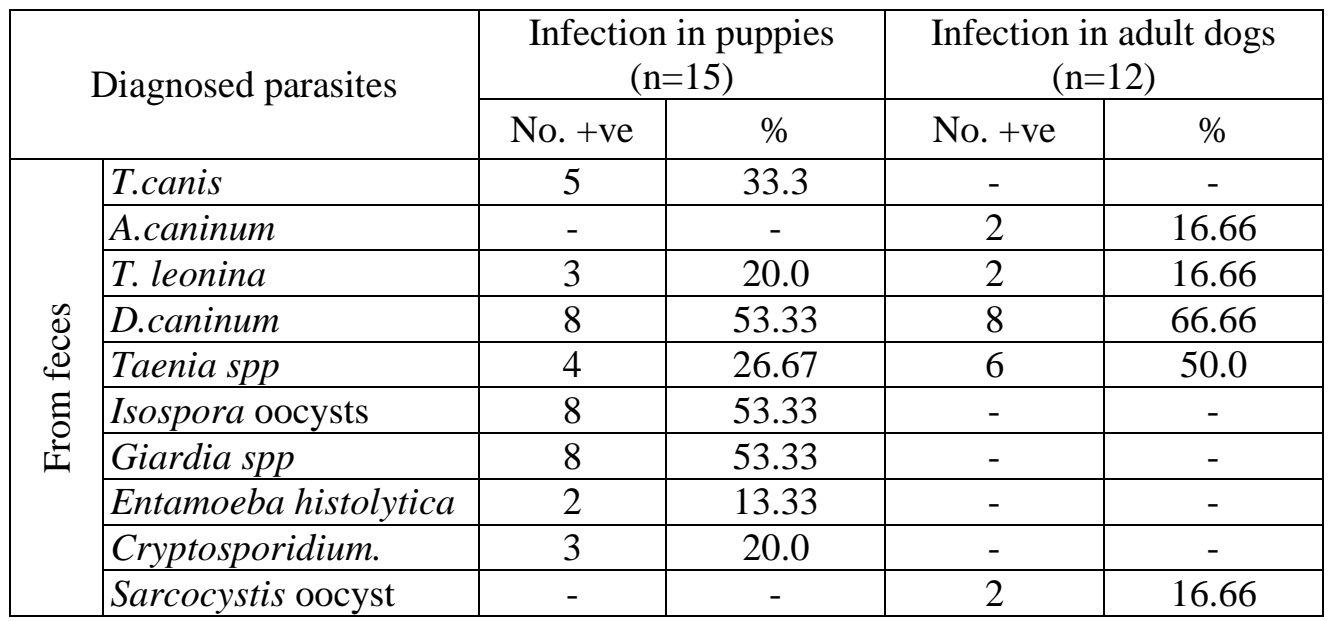

Table 3: Distribution of different pathogens in the examined attendants.

\begin{tabular}{|c|c|c|c|c|c|c|c|c|c|c|c|c|c|c|}
\hline \multirow{2}{*}{ Source } & \multirow{2}{*}{ Pathogen types } & \multicolumn{5}{|c|}{ Dog workers } & \multicolumn{7}{|c|}{ Other workers } & \multirow{2}{*}{ Total / \% } \\
\hline & & 1 & 2 & 3 & 4 & 5 & 1 & 2 & 3 & 4 & 5 & 6 & $7-10$ & \\
\hline \multirow{3}{*}{ 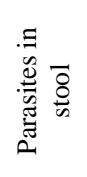 } & Giardia & + & + & & + & & & & & & & & & $3 / 20$ \\
\hline & Entamoeba & + & + & + & & & & & & & & & & $3 / 20$ \\
\hline & Isospora & & + & + & + & + & & & & & & & & $4 / 26.6$ \\
\hline \multirow{3}{*}{ 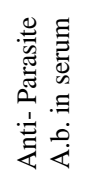 } & Anti- Toxocara & & & & & & + & + & + & & & & & $3 / 20$ \\
\hline & Anti- Sarcocystis & + & & & & + & & & & + & + & + & & $5 / 33.3$ \\
\hline & Anti- Hydatid & & + & & & + & + & + & + & + & & + & & $7 / 46.6$ \\
\hline \multirow{3}{*}{ 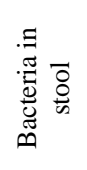 } & E.coli & + & + & + & + & & + & + & & & + & & & $7 / 46.6$ \\
\hline & Salmonella & & + & + & + & & & & & & & & & $3 / 20$ \\
\hline & Campylobacter & + & & + & & & & & & & & & & $2 / 13.3$ \\
\hline \multicolumn{2}{|r|}{ Remarks } & $D^{*}$ & D & \multicolumn{2}{|c|}{ D i D } & $\mathrm{D}$ & \multicolumn{2}{|c|}{ D D } & & & & & & \\
\hline
\end{tabular}

* $\mathrm{D}=$ animal has diarrhea

Table 4: Different bacterial pathogens diagnosed in the examined dogs: 
Assiut Vet. Med. J. Vol. 55 No. 120 January 2009

\begin{tabular}{|c|c|c|c|c|c|c|c|c|}
\hline \multicolumn{3}{|c|}{ Examined cases } & \multicolumn{2}{|c|}{$\begin{array}{c}\text { Enterotoxigenic } \\
\text { E. coli }\end{array}$} & \multicolumn{2}{|c|}{ Salmonella } & \multicolumn{2}{|c|}{ Campylobacter } \\
\hline & & No. & $\begin{array}{c}\text { No. } \\
\text { positive }\end{array}$ & $\%$ & $\begin{array}{c}\text { No. } \\
\text { positive }\end{array}$ & $\%$ & $\begin{array}{c}\text { No. } \\
\text { positive }\end{array}$ & $\%$ \\
\hline \multirow{3}{*}{$\frac{\mathscr{a}}{2}$} & Diarrheic & 7 & 5 & 71.4 & 4 & 57.1 & 3 & 42.9 \\
\hline & Non diarrheic & 8 & 2 & 25.0 & 1 & 12.5 & 2 & 25.0 \\
\hline & Total & 15 & 7 & 46.67 & 5 & 33.3 & 5 & 33.3 \\
\hline \multirow{3}{*}{ 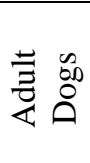 } & Diarrheic & 5 & 4 & 80 & 3 & 60.0 & 2 & 40.0 \\
\hline & Non diarrheic & 7 & 3 & 42.9 & 2 & 28.6 & 2 & 28.6 \\
\hline & Total & 12 & 7 & 58.33 & 5 & 41.67 & 4 & 33.33 \\
\hline
\end{tabular}

Table 5: Serological identification of the isolated Salmonella.

\begin{tabular}{|l|c|c|c|c|c|c|c|}
\hline \multirow{2}{*}{ Source } & Total & \multicolumn{2}{|c|}{ S. typhimurium } & \multicolumn{2}{c|}{ S. enteritidis } & \multicolumn{2}{c|}{ Un-typed } \\
\cline { 3 - 8 } & No. & No. & $\%$ & No. & $\%$ & No. & $\%$ \\
\hline Attendants & 3 & 2 & 66.67 & 1 & 33.3 & - & - \\
\hline Dogs & 10 & 6 & 60 & - & - & 4 & 40.0 \\
\hline Total & 13 & 8 & 61.53 & 1 & 7.7 & 4 & 30.8 \\
\hline
\end{tabular}

Table 6: Serological identification of the isolated Campylobacter.

\begin{tabular}{|c|c|c|c|c|c|c|c|}
\hline \multirow{2}{*}{ Source } & Total & \multicolumn{2}{|c|}{ C. jejuni } & \multicolumn{2}{c|}{ C. coli } & \multicolumn{2}{c|}{ Un-typed } \\
\cline { 3 - 8 } & Nolates & No. & $\%$ & No. & $\%$ & No. & $\%$ \\
\hline Attendants & 2 & 2 & 100 & - & - & - & - \\
\hline Dogs & 9 & 4 & 44.4 & 3 & 33.3 & 2 & 22.2 \\
\hline Total & 11 & 6 & 54.54 & 3 & 27.27 & 2 & 18.18 \\
\hline
\end{tabular}

Table 7: Serological identification of the isolated Enteropathogenic E. coli.

\begin{tabular}{|c|c|c|c|c|c|c|c|c|c|c|c|c|c|}
\hline \multirow{2}{*}{$\begin{array}{c}\text { Source of } \\
\text { isolates }\end{array}$} & \multirow{2}{*}{$\begin{array}{c}\text { Total } \\
\text { isolates } \\
\text { No. }\end{array}$} & \multicolumn{2}{|c|}{ O 26} & \multicolumn{2}{|c|}{ O 76} & \multicolumn{2}{|c|}{ O 55} & \multicolumn{2}{|c|}{ O 5} & \multicolumn{2}{|c|}{ O 111} & \multicolumn{2}{|c|}{ untyped } \\
\hline & & No & $\%$ & No & $\%$ & No & $\%$ & No & $\%$ & No & $\%$ & No & $\%$ \\
\hline Attendants & 7 & 2 & 28.57 & 2 & 28.57 & 1 & 14.28 & - & - & - & - & 2 & 28.57 \\
\hline Dogs & 14 & 3 & 21.43 & 1 & 7.14 & 3 & 21.43 & 2 & 14.28 & 3 & 21.43 & 2 & 14.28 \\
\hline Total & 21 & 5 & 23.80 & 3 & 14.28 & 4 & 19.04 & 2 & 9.52 & 3 & 14.28 & 4 & 19.04 \\
\hline
\end{tabular}


Table 8: Antibiotic sensitivity of the isolated bacteria from human and dogs.

\begin{tabular}{|l|c|c|c|c|c|c|}
\hline \multirow{2}{*}{ Antibiotic disc } & \multicolumn{2}{|c|}{ E. coli $(21$ isolates) } & $\begin{array}{c}\text { Campylobacter } \\
(11 \text { isolates })\end{array}$ & \multicolumn{2}{c|}{$\begin{array}{c}\text { Salmonella } \\
(13 \text { isolates })\end{array}$} \\
\cline { 2 - 7 } & No. +Ve & $\%$ & No. +Ve & $\%$ & No. +Ve & $\%$ \\
\hline Gentamycin (10 ug) & 19 & 90.48 & 10 & 90.9 & 12 & 92.37 \\
\hline Tetracyclin (30 ug) & 18 & 85.71 & 10 & 90.9 & 12 & 92.37 \\
\hline Ampicillin (10 ug) & 18 & 85.71 & 9 & 81.81 & 12 & 92.31 \\
\hline Amoxicilin (20 ug), & 17 & 80.95 & 9 & 81.81 & 11 & 84.61 \\
\hline Nitrofurantoin (300 ug) & 15 & 71.43 & 8 & 72.72 & 10 & 76.92 \\
\hline Kanamycin (30 ug) & 17 & 80.95 & 9 & 81.81 & 10 & 76.92 \\
\hline Cephalothin (30 ug) & 15 & 71.43 & 8 & 72.72 & 10 & 76.92 \\
\hline Streptomycin (10 ug) & 15 & 71.43 & 8 & 72.72 & 10 & 76.92 \\
\hline
\end{tabular}

\section{DISCUSSION}

Zoonotic organisms such as viruses, bacteria or parasites can possess the potential role to cause severe diseases in both humans and animals. Free-ranging animals with sporadic or indirect contact to domestic livestock and humans may serve as reservoirs or sentinels for diseases Kemper et al., (2006). So that continuous contact between diseased or carrier dogs and their workers under non proper hygienic measures initiate development of endemic foci for spreading of different pathogens, specially zoonotic one of direct life cycle, (Pullola et al., 2006).

Groups of natural parasite infected stray dogs and puppies were selected aiming to test the efficacy of anti-nematodal drugs. They remained under observation for eight weeks post treatment where their fecal samples were examined weekly. At the end of this period animals were left for another four weeks without examination waiting for another drug trail. At this time dogs' attendants were complained with variable degrees of weakness, diarrhea, abdominal pain and fever. These observations incriminate the captive dogs as a potential source for this problem. The present study investigates the different types of parasites and bacteria diagnosed in the captive dogs and their direct and some of remote contact attendants as detailed describe in this work. Parasitological investigation of these dogs evidenced infection by nine parasites include, 3 nematodes as $T$. canis in puppies (66.6\%), A. caninum in adults (41.66\%) and T. leonina in both of them $(20 \%$ and $50 \%$ respectively). In addition two cestodes include, $D$. caninum (13.33\% and 66.6\%) and Taenia spp. eggs (20\% and 50\%) in puppies and adults respectively. Moreover, four protozoan parasites include, 
Isospora, Cryptosporidium and Sarcocystis spp. oocysts as well as Giardia cysts were detected as demonstrated in Table (1). The previously diagnosed parasites considered to be common diagnosed in stray dogs and most of them pose a significant threat to human health. This was agreed with several authors allover the world (Eguia-Aguilar et al., 2005, Pullola et al., 2006; Martinez-Moreno et al., 2007).

Re-examination of these dogs' feces, at time of attendant illness, evidenced re-appearance of new nematodal infection which included $T$. canis $33.3 \%$ in puppies, A. caninum, $16.66 \%$ in adults and T. leonina $20 \%$ and $16.66 \%$ in puppies and adults respectively. There is a relatively increase in previously recorded cestodal infection in puppies than before. Meanwhile, the recorded incidences of infection by Cryptosporidium and Sarcocystis species oocysts decrease. On the other hand marked increase was recorded in the incidence of infection by Isospora and Giardia than before. An interesting finding at this time is appearance of new infection by E. histolytica (13.33\%) in puppies as in Table (2). The increase in incidence of $D$. caninum, may be due to indirect transmission of this parasite via fleas of wild cats and rodents that easily gain access to dogs boxes (Kemper et al., 2006). While increase in Taenia species in puppies explains development of new worms till shedding of gravid segments. The increase in the rate of infection by Giardia, and Isospora, may be due to presence of parasite infective stages whereas contamination of the environment through fecal shedding around these animals. Moreover, transmission of these parasites can occur directly from a reservoir to the susceptible animal or human being (Solusby 1986). Reappearance of A. caninum \& T. canis may be due to development of some migrating larvae success to escape from the applied treatment. The decrease in the recorded Sarcocystis and Cryptosporidium oocysts, was related to the nature of these parasites life cycles, as they shed early as an acute form then the animal keep the infection and still as carrier after this, (Levine et al., 1980).

In order to follow-up the condition in attendants, stool examination of closely contact attendants ( 5 persons) and remote contact (10 persons) as in Table (3), revealed infection by three protozoon parasites include Giardia, E. histolytica (20\%) and Isospora oocysts (26.6\%). All of these parasites were diagnosed in workers that closely contacts to dogs and complained with digestive disturbances and diarrhea. These parasites are previously described that they have zoonotic importance (Acha and Szyfres 1991). 
Although E.histolytica infection was not diagnosed in first feces examination of captive dogs, it was recorded in attendants after three months contact with dogs. This finding suggests that this parasite transmitted from the attendants to dogs. On the contrary, Giardia and Isospora infection were recorded only in workers that are in close contact to dogs. It was thought that dogs are the main source of attendants' infection with these parasites as they were previously diagnosed in it and no diarrhea problem in workers at this time. This was agreed with Acha and Szyfres (1991) as dog, cat and man sharing each other as final hosts for E. histolytica, Giardia and Isospora with high degree of adaptation between the three species.

On the other hand, examination to sera of these attendants using ELISA revealed presence of antibodies (Ab) against T.canis (20.0\%), Sarcocystis (33.3\%) and Hydatid cysts (46.6\%), table (3). Presence of anti-parasite IgG antibodies in sera means chronic infection (Sadjjadi, 2007) this may reflect infection from the present dogs as well as due to old infection attributed to their occupation.

With respect to detected anti-Toxocara and anti-hydatid cysts antibodies in sera of examined workers, the captive dogs under test condition were not responsible for this infection, whereas, Echinococcus granulosus infection wasn't diagnosed in them. In addition, the diagnosed anti-Toxocara antibodies were detected in workers that not in closed contact with these dogs, so they may be took this infection from other dogs during previous exposure. It worthy to mention that examined dogs could or could not considered responsible for the detecting antiSarcocystis antibodies in sera of examined workers. This due to presence of infection by Sarcocystis oocysts in feces of dogs, while the antibodies diagnosed in closed contact as well as the other workers.

At the aspect of enteric bacteria associated with diarrhea and cause illness in the contact workers, bacteriological examination of workers fecal samples (Table 3) revealed isolation of Enteroinvasive E. coli (EIEC) from 7/15 human (46.6\%), Cambylobacter from 2/15 $(13.3 \%)$ and Sallmonella from 3/15 (20.0\%). It is worthy to mention that E. coli infection was associated with diarrhea in four of direct contact workers and only two of other ten non contact workers. Meanwhile, Salmonella and Campylobacter infection were recorded in diarrheic close contact workers only.

Our findings confirm that the diagnosed symptoms in morbid cases considered due to infection by these bacteria (Salmonella, Campylobacter and EIEC). This was agreed with (Batt 2002) as he 
mentioned that these pathogens have been clearly associated with acute and chronic disease, typically causing diarrhea combined with tenesmus, vomiting, in-appetence, malaise, lethargy and abdominal pain are more variably encountered.

On the other side investigation of captive dogs by the same way (Table 4), evidenced infection by E. coli, $46.66 \%$ and $58.33 \%$ in puppies and adult dogs respectively. Infection by Salmonella was $33.3 \%$ and $41.66 \%$ in both groups respectively and finally infection by Campylobacter was $33.3 \%$ in both groups of dogs. Infection by these bacteria associated with diarrhea in both dogs and puppies. These results are in agreement with (Hall and Simpson, 2000) as Salmonella sp., Campylobacter sp and EIEC are the main enteropathogens that are most commonly identified in dogs. Moreover, Hart (1993) demonstrated that there is relatively little information about the prevalence of pathogenic $E$. coli in dogs, but there is good evidence that they may play a role in the pathogenesis for both acute and chronic diarrhea. While Campylobacter species causing diarrhea in dogs, cats, and humans especially in young. Adult animals commonly have Campylobacter organisms living in their intestines but they do not experience any sickness due to it. Dogs can infect people whether they have diarrhea or not (Brook 2006).

It has been estimated that the isolation of the same pathogens from human demonstrates that they are mainly originated from these dogs. This was agreed with Hall (2004) as dogs act as hosts to numerous intestinal bacteria (especially what mentioned above). This creates risks for zoonotic pathogens transmission to human through direct contact and environmental contamination.

Concerning sterotyping of the diagnosed isolates, number of 13 Salmonella isolates sub-typed as, S. typhimurium (8), S. enteritides (1) in human and untyped isolates (4) from dogs, (Table 5). Eleven isolates of Campylobacter as C. jejuni (6), C.coli (3) and two untyped species, (Table 6). Moreover that, twenty one E. coli isolates were affiliated to five sero-groups as O26 (5), O76 (3), O55 (4), O99 (2), O111 (3) and four un-typable isolates, (Table 7).

S. typhimurium and $S$. enteritides are known as more common in animals as well as causing human food poisoning. Most human cases of Salmonella infection cause fever, diarrhea, and cramping that go away on their own. The disease is more severe in children, puppies and kittens, (Brook, 2006). Likewise, $C$. jejuni is a major cause of infectious enteritis in human (Abdel-Aty and Rabie 2003) and exposure to a dog 
with diarrhea triples a person's risk for developing enteritis from $C$.jejuni or C. coli (Brook, 2006). Moreover, dogs act as carriers for many enteropathogens, and the development of clinical disease may involve environmental factors such as stress and an innate inability to mount an effective mucosal immune response. Active carriers tend to shed organisms continuously or intermittently, while latent carriers shed only when under stress (Batt, 2002).

In the same time, persistence of infection around dogs was affected by survival time of each pathogen. Campylobacter can survive for days in surface water and as long as 4 weeks in feces; in addition, the duration of excretion in infected dogs can be as long as 4 months. (Hall, 2000). Salmonella organisms are very difficult to remove from the environment, it easily to survive for 3 months in aquatic environments and in soil, shedding may continue for 3 to 6 weeks, and can be reactivated at a later date by any inter-current stress, (Brook, 2006).

In order to identify specific antibiotic for the different isolates, anti- biotic sensitivity test was performed as described in Table (8). The tested isolates showing sensitivity for each of Gentamycine (10 ug) and Tetracycline $(30 \mathrm{ug}$ ) enriched disks. The study advised to treat the morbid animal cases by Gentamycine $5 \mathrm{mg} / \mathrm{Kg} . \mathrm{B} . \mathrm{W}$. orally for 5 consecutive days (Schering-Plough Animal Health USA) with intravenous fluid therapy especially for puppies. According to Thompson and Roberts (2001) treatment of animals is considered to be one of the fastest ways for eradication of different pathogens.

It has been estimated that captivity condition act as stress factor depress the host resistance and increase their susceptibility to infection and spread new pathogens. In the Authors opinion, captivating of dogs under condition of the present study initiate development of endemic foci, as the infective stages were disseminated from infected dogs, in suitable conditions of dust, shad and moisture, these led to its propagation and persistence in the nature especially in and around the animal boxes so do potential zoonotic risks.

The study concluded that, captive dogs waiting for experimental studies must be thoroughly examined for all suspected pathogens, kept under strict hygienic measures under continuous observation along they remained in contact to human and didn't feed raw food. Animal workers must be educated about transmission of different diseases. Moreover they must be trained about how can they protect themselves from infection? In animal boxes, cleaning and disinfecting methods must be regularly applied inside and outside these boxes and completely 
separated from the surrounding area as well as it should be protect from rodents and vectors.

However, viral infection diagnosed in diarrheic workers and dogs, detailed description to the adopted way of treatment and important recommendation concerning minimize spreads of infection from these poxes well be demonstrated in another separate paper.

\section{REFERENCES}

Acha, S. and Szyfres, F. (1991): Zoonoses and Communicable Diseases Common to Man and Animals (2 "d Ed.). Pan American Sanitary burea, 525 Twenty third street, N.W. Washington, D.C. 20037, USA.

Abdel -Aty, E.A. and Rabie, N.S. (2003): Immunogenic properties of outer membrane protein of C. jejuniin in chicks. Vet. Med. J. Giza: 51(1), 95-104

Batt, R.M. (2002): Bacterial enteropathogens in dogs. Masterfoods, Mars Inc. WSAVA,

Bauer, A.W.; Kirby, W.M.; Sherris, J.C. and Turck, M. (1966): Antibiotic susceptibility testing by a standardized single disc method. Am. J. Clin. Pathol. 45: 493-496.

Brook, W.C. (2006): Campylobacter, Salmonella, and E. Coli: Causes of Diarrhea in Page 10.

Egulia-Aguilar, P.; Cruz-Reyes, A. and Martinez-Maya, J.J. (2005): Ecological analysis and description of the intestinal helminthes present in dogs in Mexico City. Vet. Parasitol., 127 (2): 139 146.

Ewing, W.H. (1986): The genus Eschereichia, P 93-134. In Ewing W.H, and Edward P.R. Identification of Enterobacteriaceae, $4^{\text {th }}$ ed. Elsevier Science, New York.

Fontanarrosa, M.F.; Vezzani, D.; Basabe, J. and Eiras (2006): An epidemiological study of gastrointestinal parasitesof dogs from southern Greater Buenos Aires (Argentina): Age, gender, breed, mixed infections, seasonal and spatial patterns. Vet. Parasito. 136: 283-295.

Gasbarret, L.C. and Fayer, R. (1984): Humeral cellular immune responses in cattle and sheep inoculate with sarcocystis. Am. J. Vet. Res., 45(1): 1592-1596.

Greene, C.E. (2006): Enteric Bacterial Infections, in Greene CE (ed), Infectious Diseases of the Dog and Cat, 339-369. 
Habluetzel, A.; Traldi, G.; Ruggieri, S.; Attili, A.R.; Scuppa, P.; Marchetti, R. Menghini,G. and Esposito, F. (2003): An estimation of Toxocara canis prevalence in dogs, environmental eggs contamination and risk of human infection in the Marche region of Italy. Vet. Parasitol., 113: 243 - 252.

Hall, E.G. (2004): Bacterial Enteropathogens in dogs. Bristol University, Langford House, Langford Bristol, UK, WSAVA congress.

Hall, E.G. and Simpson, K.W. (2000): Diseases of the small intestine. Text book of Veterinary Internal Medicine, $5^{\text {th }}$ Ed, WB Saunders, Philadelphiaa, pp 1182-1238.

Hart, C.A.; Batt, R.M. and Saunders, J.R. (1993): Diarrhoea caused by Escherichia coli, Ann. Trop Paediat, 13, 121-131.

Ito, A.; Ma, L.; Schantz, P.M.; Gottstein, B.; Liu, Y.H.; Chai, J.J.; Abdel-Hafez, S.K.; Altintas, N.; Joshi, D.D.; Lightowlers, M. and Pawlowski, Z.S. (1999): Differential serodiagnosis for cystic and alveolar echinococcosis using fractions of Echinococcus granulosus cyst fluid (antigen B) and E. multilocularis protoscolex (EM18). Am. J. Trop. Med. Hyg.: 60 (2): 188-92.

Kagan, I.G.; Jeska, E.L. and Gentzkow, C.J. (1958): Serum agar double diffusion studies with Ascaris antigens: Assay of whole worm and tissue antigen complexes. J. Immunol, 80, 400-406.

Kauffmann, F. (1972): Serological diagnosis of Salmonella species, Kuffmann- white scheme, Munksggard, Copenhagen, Denmark.

Koneman, E.W.; Steven, D.A.; Dowell, V.R.; William, M.G. and Washington, C.W. (1992): Diagnostic Microbiology, $4^{\text {th }} \mathrm{Ed}$, J.B. Lippineatt Co. Philadelphia, USA.

Kemper, N.; Aschfalk, A. and Holler, C. (2006): Campylobacter spp., Enterococcus spp., Escherichia coli. Salmonella spp., Yersinia spp., and Cryptosporidium oocysts in semi-domesticated reindeer (Rangifer tarandus tarandus) in Northern Finland and Norway Acta Veterinaria Scandinavica, 48:7doi:10.1186/17510147-48-7.

Langley, R.J.; Hillyer, G.V. (1989): Detection of circulating parasite antigen in Murine fascioliasis by two-site enzyme-linked immunosorbent assays. Am. J. Trop. Med. Hyg., 41, 472-478. 
Levine, N.D.; Corliss, J.O.; Cox, E.E.; Varava, J. and Wallace, F.G. (1980): A newly revised classification of the protozoa. J. of Protozoology, 27: 37-58.

Lowry, O.H.; Rosenbrough, N.J.; Farr, A.L. and Randall, R. (1951): Protein measurement with the phenol reagent. J. Biol. Chemis., 193: 265-275.

Martinez-Moreno, F.J.; Hemandez, S.; Lopez-Cobos, E.; Becerra, C.; Acosta, and Martinez-Moreno, A. (2007): Estimation of canine intestinal parasites in Cordoba (Spain) and their risk to public health. Vet. Parasitol., 143 (I): 7 - 13.

Pullola, T.; Viermaa, J.; Saari, S.; Virtala, A. M.; Nikander, S. and Sukura, A. (2006): Canine intestinal helminthes in Finland: Prevalence, risk factors and endoparasite control practices. Vet. Parasitol., 140 (3-4): 321-326.

Quinn, P.J.; Carter, M.E.; Markey, B. and Carter, G.R. (1994): Clinical Veterinary Microbiology. Mosby, U.K.

Sadjjadi, S.M., Abid, H, Sarkani, B., Izadpanah , A., Kazemina, S., (2007): Evaluatuin of ELISA, utilizig native antigen B for Serodiagnosis of human hydatidosis. Iran. J. Immunol. 4, (3), 167-169.

Sabry, M.A. (2007): Advanced concepts in diagnosis of hydatidosis in human and living animals. J. Bio. Sci. 7 (5): 720-728.

Sabry, M.A. and Reda W.W. (2008): Infection by cyst producing protozoa among human and food producing animals in Egypt. J. Biol. Sci. 8 (5): 889-895.

Soulsby, E.J. (1986): Helminthes, Arthropoda and Protozoa of Domesticated Animals. $7^{\text {th }}$ ed. Bailliere Tindal \& Casell Ltd. London.

Thompson, A.R. and Roberts, M.G. (2001): Does pet helminth prophylaxis increase the rate of selection of drug resistance?. Trends in Parasitol., 17 (12): 576 - 578.

Voller, A.; Bidwell, D. and Bartlett, A. (1976): Enzyme immunoassays in diagnostic medicine. Theory and Practice. Bulletin of the World Health Organization, 53: 55-65.

Zimmerman, G.; Nelson, M.J. and dark, G.R.B. (1985): Diagnosis of ovine fascioliasis by a dot enzyme-linked inimunosorbent assay. A rapid microdiagnostic technique. Atn. J. Vet. Res., 46: 15 13-1515. 